\title{
Ascensão e queda de Jaime Bunda: como o espantoso detetive angolano se relaciona com o mito de Ícaro
}

\author{
Regina Chamlian ${ }^{1}$
}

RESUMO: Este ensaio toma como ponto de partida a reflexão de Benjamin Abdala Junior sobre a conexão entre os trabalhos de Pepetela e o mito de Ícaro, relacionados através da estrutura de ascensão e queda dos sonhos libertários e desejos utópicos, e busca investigar se isso também ocorre em Jaime Bunda, agente secreto, publicado em 2001.

ABSTRACT: This essay takes as its point of departure the Benjamin Abdala Junior's reflection about the connection between the work by the Angolan writer Pepetela, and the myth of Icarus, by relating them through the structure of the rise and fall of libertarian dreams and utopian desires. The paper also aims to investigate if these elements appear in the novel Jaime Bunda, agente secreto (2001), as well.

PALAVRAS-CHAVE: Pepetela; Mito de Ícaro; Ascensão; Queda; Sonhos libertários; Desejos utópicos.

KEYWORDS: Pepetela; myth of Icarus; Rise; Fall; Libertarian dreams, Utopian desires.

A obra de Pepetela pode ser relacionada com a estrutura de ascensão e queda dos sonhos libertários, como no mito de Ícaro, o que pode ser percebido "quer focalizemos as atitudes das personagens, quer o desenvolvimento do conjunto de sua obra”. O mito de Ícaro, entendido como figuração da utopia libertária, simboliza o desejo humano de voar. É o voo que liberta das prisões, históricas ou psicológicas, e propicia a visão e a construção de novos horizontes, mais amplos e significativos (ABDALA JUNIOR, 2003, p. 239; 241-242; 14-15).

1 Doutoranda em Estudos Comparados de Literaturas de Língua Portuguesa. Universidade de São Paulo (USP). Projeto de Pesquisa: João Carlos Marinho e Pepetela: dois escritores em ponto de bala - o gênero policial em Berenice detetive e Jaime Bunda, agente secreto. Contato: reginacham@bol.com.br 
Focalizando neste trabalho a personagem-titulo de Jaime Bunda, agente secreto, através da caracterização e atos que lhe atribuiu seu irônico autor, buscarei comentar, não conclusiva e nem exaustivamente, como se dá a oscilação da personagem entre os movimentos de ascensão e de queda dos sonhos e utopias libertárias.

Sonhos e utopias libertárias são entendidos aqui como construções da imaginação e da práxis humana que desestabilizam a rigidez das hierarquias presentes na vida em sociedade, rompem os grilhões que enredam pessoas e países em relações assimétricas, questionam e modificam ideias e ações tidas por inquestionáveis, criando alternativas ao real e transformando o mundo num lugar melhor, aqui e agora, e também no futuro.

Semelhantes projetos e práticas libertárias remetem à compreensão contemporânea de que não há em nossos horizontes "um" único inimigo da liberdade: as opressões são múltiplas. Patriarcalismo e machismo, racismo, consumismo, degradação da natureza, controle social, intolerância, autoritarismo, burocracia, exploração do trabalho, coisificação do outro, entre outras formas de imposições hegemônicas e cerceamentos, seriam algumas dessas cadeias que é preciso quebrar (SANTOS, 2000, p. 23-37).

Para Boaventura de Souza Santos, tais transformações em direção à(s) utopia(s) só podem ser realizadas por subjetividades rebeldes subjetividades conformistas imobilizariam essas aspirações (SANTOS, 2000, p. 33; 330).

Por conseguinte, subjetividade rebelde seria aquela inclinada a romper com os elos opressivos acima mencionados e capaz de voar. A este campo semântico do movimento de ascensão pertencem as ideias de libertação da gravidade, correr velozmente, coragem, entusiasmo, alento, impetuosidade, imaginação, inspiração, leveza, movimento, agilidade, principio de juventude, esperança, desejo de conhecimento, mudança, paixão... tudo o que trama a favor dos projetos utópicos.

Em sentido contrário, subjetividade conformista seria aquela que impõe e suporta os vários aprisionamentos sendo, portanto, incapaz de 
voar e propensa à queda. Ao movimento de queda se associam ideias de peso, morosidade, obediência, temor, submissão às leis da gravidade, imobilidade, certa "materialidade terreal", manutenção do status quo, desesperança, fracasso, prostração... tudo o que conspira contra os sonhos libertários.

\section{A bunda}

Para compreender como é construída a personagem-título de Jaime Bunda, agente secreto em torno do par de opostos ascensão e queda, começo pela característica superlativa que the angariou $o$ "sobrenome": a bunda. Deixando de lado aqui a óbvia alusão a "Bond", de James Bond, parodiado no romance, ao nosso detetive é atribuída uma qualificação que o distingue do exterior, como nas caricaturas ou nas chamadas personagens planas. O que nos interessa, por ora, é como este formidável atributo marca as ações da personagem e que sentido parece lhes conferir. Herança da mãe, uma senhora que tem um "valente traseiro", a bunda de Jaime é descrita como "avantajada", "exagerada em relação ao corpo", "as suas nádegas exageravam". O detetive "esperava pacientemente na sala, sentado na mesma cadeira,... amolgando a cadeira com o peso da sua bunda" (p. 13). Ficamos sabendo também que "o estagiário Jaime Bunda não corria, era contra os seus principios de vida" (p. 12). E que o peso de sua bunda praticamente o gruda ao assento, exigindo do detetive um esforço hercúleo para erguê-la dali, como o chefe Chiquinho não deixa de notar: "Como é que um tipo tão novo podia demonstrar tanto esforço e sofrimento para se levantar de uma cadeira? Os suspiros de Jaime Bunda eram de cortar o coração..." (p. 17). Ao sair do gabinete do chefe, o detetive "virou em câmera lenta para a saída e nunca, nunca mesmo, o chefe Chiquinho viu alguém demorar tanto tempo até chegar à porta, abri-la e desaparecer" (p. 17).

Todas as atribuições acima referidas esboçam/desenham/se associam com ideias de peso, imobilidade, morosidade, oposição ao 
princípio de juventude, materialidade terreal, submissão à lei da gravidade - que se relacionam ao movimento de queda. A portentosa bunda do detetive angolano, em princípio, é elemento da caracterização que o inclinaria à queda.

\section{A personagem enquanto detetive}

Comento brevemente agora a ação da personagem enquanto detetive, no próprio curso da investigação que lhe foi confiada. Depois de longo tempo sentado esmagando e moldando com a bunda o assento de sua cadeira da sala de detetives, Jaime é finalmente chamado a investigar um caso. Trata-se de uma menina violada e assassinada, menina pobre, de apenas catorze anos, uma ocorrência considerada banal. O detetive-estagiário começa sua investigação inspirado pelos livros policiais de norte-americanos e ingleses que lê desde a infância onde aprendeu que "o crime não compensa e que não há crimes sem solução, mas investigadores que não vão até o fim". Movido por essas conviç̧ões, sua insistência detetivesca o põe no rastro de certo senhor $\mathrm{T}$, alto figurão do governo angolano. Ao saber do andamento das investigações o chefe de Jaime, Chiquinho Vieira, o aconselha a alterar o rumo do inquérito e mirar em outra direção. Jaime, no entanto, desobedece ao chefe e continua na pista do figurão, sempre movido pela ideia de que o trabalho do detetive é investigar e descobrir a verdade, chegando a saltar da cadeira quando se lembra de algo que o porá no encalço do todo-poderoso senhor $\mathrm{T}$, para a perplexidade de seu superior:

De repente Jaime Bunda saltou da cadeira. Literalmente. O chefe mais pasmado ficou, pois sabia a dificuldade que o outro tinha em se levantar, nunca ninguém era tão lento e demonstrou tão visível máscara de sofrimento. Desta vez, picado por uma surucucu ou lacrau, o certo é que o agente estagiário se pôs de pé num instante, pediu desculpa, chefe, lembrei-me agora de uma coisa vital, e saiu quase a correr, deixando o superior de novo sem fôlego ao ver a agitação que percorria aquela bunda a alcançar a porta (PEPETELA, 2003, p. 97). 
A atitude impetuosa e desobediente de Jaime acabará por levá-lo a desbaratar uma quadrilha de falsificadores de kwanzas (moeda angolana) que preparava um grande golpe contra a economia de seu país. Em outro desdobramento da narrativa, com relação ao assassinato da menina, Jaime Bunda pressiona Kinanga, funcionário de outra repartição estatal, com visitas costumeiras para filar uísque e conversar sobre romances policiais e sobre o caso que têm em mãos, visitas que Kinanga considera enigmáticas e preocupantes e que o constrangem a prosseguir na investigação do caso (em vez de deixá-lo para lá por considerá-lo irrisório) e a encontrar o culpado, que vem a ser o filho de um importante deputado.

Independentemente do fato do senhor T escapar incólume do caso da falsificação de kwanzas e de se duvidar, na própria narrativa, da justa punição ao filho do deputado, interessa-nos aqui o conjunto das ações da personagem enquanto detetive. Tais ações configuram uma subjetividade rebelde, com marcas insuspeitas de leveza, velocidade, espírito de desafio, desejo de conhecimento da verdade, desobediência, impetuosidade e imaginação, e o relacionam ao movimento de ascensão.

\section{A relação com as mulheres}

Outro aspecto da construção da personagem diz respeito a seu relacionamento com as mulheres. Jaime Bunda tem uma namorada, a Florinda, mulher casada com um kamanguista (traficante de diamantes), ao qual o detetive pretende suplantar. Florinda é uma angolana bonita, experiente, mais velha do que ele, e pouco afeita à submissão. Pelo contrário, ela namora com Jaime para conseguir dele informações privilegiadas para proteger seu marido, que também desconhece esse arranjo. Apaixonado por Florinda, porém sofrendo a concorrência do marido, o detetive contrata um sujeito para lhe dar uma surra e afastá-lo do país, mas o tiro lhe sai pela culatra. Uma furiosa Florinda, ao descobrir o que Jaime Bunda pretendeu fazer, dá- 
lhe uma grande surra, unhando-lhe a cara e enchendo-o de bofetões, deixando-o com o rosto muito machucado e o olho inchado, o que mais tarde será propagandeado pelo detetive como resultante de um ataque de bandidos. Despeitado pelo rompimento e humilhação que lhe infligiu a namorada, Jaime Bunda olha com novo interesse para Solange, a secretária linda e burra do chefe Chiquinho Vieira:

Mil vezes melhor que Florinda. E jovem, carne fresca. Com a vantagem de ser conhecida como burra, o que implicava pouca capacidade de armar em evoluída independente, a dizer constantemente ninguém manda em mim, como começavam a surgir alguns exóticos personagens agora, herdeiros do finado processo revolucionário e da dita campanha de emancipação da mulher. (PEPETELA, 2003, p. 129)

Ainda que o imaginário do detetive esteja povoado pelas fantasias masculinas hegemônicas de um James Bond, por exemplo, e pelas determinações machistas de sua própria cultura, como em "só homem pode ter duas mulheres, nunca o inverso, isto é adultério" (pág. 69), Jaime Bunda escolheu uma namorada difícil de dominar. Até o fim do romance, seus pensamentos verdadeiramente amorosos se voltarão apenas para Florinda. Na prática, o detetive se deixou levar pela paixão, pelo ardor que sentia por ela, e não por sua adequação aos ritos patriarcais. Os pensamentos que ele expressa a esse respeito durante a narrativa, no entanto, em relação à Florinda, à Solange ou a outras mulheres, se associam com o campo da opressão e, nos termos aqui propostos, estão relacionados com o movimento da queda. Mas a Florinda "real" não se adequou ao figurino e quebrou suas expectativas. Suas fantasias de supremacia em relação a ela foram logradas. Este quebrar das expectativas machistas dominadoras, o rotundo fracasso do detetive nestas suas intenções, acaba aproximando a personagem, através de sua dolorosa (e hilariante para nós leitores) experiência, ao campo da ascensão. No tocante ao relacionamento de Jaime Bunda com as mulheres, portanto, as imagens de ascensão e queda coexistem e não encontram, pelo menos neste romance, uma mais acabada solução.

\section{A comicidade da personagem}


Um aspecto de grande importância que marca a personagem como um todo é seu caráter cômico, que não será estudado aqui. No entanto, ainda que de passagem, creio ser relevante mencionar esta presença na caracterização de nossa personagem. Como sabemos, o riso tem a capacidade de desestabilizar e criticar as hierarquias, de desmontá-las e apresentá-las como ridículas, o que subverte a ordem estabelecida e tem efeito libertador. Esta poderosa arma política de crítica social, por si, constrói espaços de rebeldia e utopia, ao não referendar o status quo. Todas as ações de Jaime Bunda que mais se aproximam àquelas que lemos como conformistas sofrerão este efeito compensador. Ainda assim, elas valerão pelo que são e seremos nós os leitores que faremos, pelo riso, este ajuste interpretativo e libertário.

\section{Considerações finais}

$\mathrm{Na}$ construção da personagem Jaime Bunda no tocante aos aspectos que tratamos - a bunda, a personagem enquanto detetive, a relação com as mulheres, sem esquecer as observações relativas à sua comicidade -, se nota uma espécie de registro híbrido, no qual um misto de conformismo e rebeldia parece mover o processo de caracterização literária, não havendo preponderância de nenhum desses movimentos, e mantendo-se, cada um deles, com acentos nítidos e fortes. Em diálogo direto com uma sociedade angolana com muitos traços distópicos - pobreza, corrupção, burocracia, máquina estatal centralizadora, nepotismo, injustiça social, criminalidade urbana, elites bem situadas como no tempo colonial, capitalismo selvagem -, a personagem parece manter, ela mesma, em sua subjetividade e em sua trajetória romanesca, aquela dimensão dialética de oscilação entre ascensão e queda dos sonhos libertários, com a qual a obra de Pepetela tem sido relacionada.

\section{Referências bibliográficas}


ABDALA JUNIOR, Benjamin. "De Vôos e Ilhas - Imagens Utópicas e o Mito de Ícaro em Recortes Clássicos e Contemporâneos" In: De vôos e ilhas. Cotia: Ateliê Editorial, 2003.

. "Notas sobre a Utopia, em Pepetela" In: De vôos e ilhas. Cotia: Ateliê Editorial, 2003.

PEPETELA. Jaime Bunda, agente secreto. Rio de Janeiro: Record, 2003.

SANTOS, Boaventura de Souza. "Por que é tão dificil construir uma teoria crítica?" In: A crítica da razão indolente: contra o desperdício da experiência. São Paulo: Cortez Editora, 2000.

. "Não disparem sobre o utopista" In: A crítica da razão indolente: contra o desperdício da experiência. São Paulo: Cortez Editora, 2000. 